"The Rose Revolution represented a victory not only for the Georgian people but for democracy globally. [It] . . . demonstrated that, by aggressively contesting elections, exercising basic freedoms of speech and assembly, and applying smart strategic thinking, a democratic opposition can defeat a weak semi-democratic kleptocracy."

\title{
Georgia's Rose Revolution
}

\author{
LINCOLN MITCHELL
}

n the afternoon of November 23, 2003, Georgia's Rose Revolution culminated with an eerie Oedipal image. Two opposition leaders, Mikhail Saakashvili and Zurab Zhvania, walked into President Eduard Shevardnadze's office. Shevardnadze had brought both men into politics and mentored them; as recently as three days earlier he had referred to them as his children. Yet on that afternoon they had come to put an end to the political turmoil Shevardnadze had fathered by overseeing fraudulent elections. A few minutes after entering his office the two emerged with Shevardnadze's resignation letter, abruptly terminating his long career as Georgia's leader.

The Rose Revolution represented a victory not only for the Georgian people but for democracy globally. The revolution that took as its symbol a red rose (held al oft by Saakashvili as he and his supporters stormed into the Parliament building on November 22) demonstrated that, by aggressively contesting elections, exercising basic freedoms of speech and assembly, and applying smart strategic thinking, a democratic opposition can defeat a weak semi-democratic kleptocracy.

\section{SHEVARDNADZE'S FATE}

Shevardnadze's final act in politics seemed an ignominious end for a figure who had been broadly lauded as one of the crucial actors in the peaceful resolution of the cold war. How did the admired diplomat who had negotiated with the United States and stood by President Mikhail Gorbachev during

LINCOLN MITCHELL is a consultant based in New York City. From 2002 to 2004 he served as director of the National Democratic Institute in Georgia.

Editor's note: This article was reviewed before publication by the $N$ ational Democratic Institute. the last days of the Soviet Union end up leading such a corrupt, ineffective regime and allow such massive election fraud?

To fully answer this question, it is essential to realize that Shevardnadze by the fall of $2002 \mathrm{had}$ been the leader of Georgia for almost 30 years, with a brief interregnum when he served as Soviet foreign minister while one of his lieutenants led Georgia. Many American and European Georgia watchers may have wondered how Shevardnadze could do such a good job as foreign minister and such a bad job as president of Georgia. But many Georgians viewed Shevardnadze's time as foreign minister as an anomaly, standing out as good work after his poor leadership from 1972 to 1985 as first secretary of the Communist Party in Georgia and before his disastrous presidency beginning in 1993.

Too many Westerners were reluctant to hold Shevardnadze responsible for Georgia's problems, while almost all ordinary Georgians blamed him personally. Many held him largely responsible for losing the rebellious territories of Abkhazia and South Ossetia during his first years as president. Shevardnadze was masterful at speaking to Western politicians and leaders on their brief visits to Georgia. $M$ any were simply excited to have a meeting and a photograph with the great statesman; few had the courage to question him about the problems in his regime. This remained true as the elections of November 2003 approached.

Shevardnadze was a brilliant politician, but he was never a real democrat. As Georgia's president, he projected himself as a leader who, because of his background, was uniquely positioned to bring about democracy and political modernity in Georgia. However, in many respects he was not unlike other former communist leaders governing newly independent countries. Shevardnadze had succeeded over the course of decades in a highly com- 
petitive political system, but not one based on democratic legitimacy.

Shevardnadze knew how to make political deals, allow political freedoms, use cronyism and corruption, and do whatever was necessary to stay in power. He also understood the value of his international reputation in presenting his administration to the West. Yet, as conditions in Georgia deteriorated during the last years of his administration, and as his closest protégés became his political opposition, it was increasingly difficult for Shevardnadze to maintain any kind of legitimacy or political strength domestically. After his party tried to steal the parliamentary elections in N ovember 2003, there was no institution strong enough to defend him when he faced somewhat modest demonstrations and very determined opposition leaders.

As G eorgia's parliamentary elections approached in the fall of 2003, corruption was rampant, privatesector growth and foreign investment had slowed, and many government officials enjoyed ill-gotten wealth and privilege. President Shevardnadze's enormous international prestige had, to a significant extent, succeeded in preventing foreign policymakers and diplomats from recognizing or coming to terms with Georgia's flawed el ectoral processes, its corruption, and its failing economy. N onetheless, Shevardnadze's political support within Georgia had begun to erode since his reelection in 2000. Zhvania, the speaker of Parliament, and Saakashvili, his justice minister, broke with the president in 2001 and 2002, as did Zhvania's replacement as speaker of Parliament, another one-time Shevardnadze protégé, Nino Burjanadze, in 2003.

By mid-2003, Shevardnadze was considerably weaker politically than he had been following the 2000 presidential election when he and his party, the Citizens Union of Georgia (CUG), appeared to be at the height of their strength. At that time, al though the economy remained weak and corruption widespread, many Georgians were pleased that Shevardnadze had managed to bring a measure of stability to Georgia, and they were beginning to enjoy greater civil liberties and freedoms. Additionally, Shevardnadze had set the country on a proWestern course and strengthened relations with Georgia's most important ally, the United States, while maintaining a delicate balancing act with Georgia's powerful northern neighbor, Russia.

\section{THE STO LEN ELECTION}

The N ovember 2, 2003, parliamentary election in Georgia was marked by rampant ballot stuffing, multiple voting, late poll openings, ballots not being delivered to some polling places, and voter lists that included dead people but excluded thousands of live voters. Moreover, when the polls closed that Sunday evening the fraud had only begun. Many opposition groups felt that, while they could combat- or even live with-a certain amount of fraud during polling hours, the fraud during the counting of the votes was potentially more dangerous. A three-party pro-government bloc controlled the Central Election Commission as well as all localand district-level election commissions. As a result, the pro-government coalition For a N ew Georgia, and in the Georgian republic of Ajara, the Revival party (the authoritarian party that controlled that southwestern region of Georgia) had ample opportunity after the polls closed to further fraudulently increase their votes.

Opposition politicians and civic groups combated election fraud at the counting stage by two means. First, the International Society for Fair Elections and Democracy, a Georgian el ection monitoring organization, conducted a parallel vote and turnout tabulation-a large, statistically valid sample of turnout and results. The group stationed observers all day in 20 percent of Georgia's polling places, where they fed observed turnout and vote totals for each party to a central data-entry office. Second, an exit poll funded by nongovernment organizations was released shortly after voting ended on Sunday. The data from both sources showed two important things: that both the Revival party and the government continued their el ection fraud in the aggregation of precinct-level results, and that, among opposition parties, Saakashvili's $N$ ational M ovement was the election's clear winner. The Burjanadze Democrats, led by Burjanadze and Zhvania, did not do as well as expected.

The preliminary results did not include Ajara, home to Georgia's most fraudulent elections. Ajaran officials waited until November 6 , after returns from the rest of the country had been submitted, to turn in their largely fabricated results, which were based on inflated turnout from inflated voter lists. The Revival party received 95 percent of the vote, exceeding estimates by even the most cynical Ajara watchers.

\section{THE ROSE BLOOMS}

Armed with the proof provided by the voting monitors and exit polls, the opposition refused to accept the election's outcome. On N ovember 4, the Burjanadze Democrats and National Movement 
began a vigil in front of Parliament. For nine days, demonstrators ranging in number from approximately 500 to 5,000 stood in front of the Parliament building to protest the vote fraud. The Burjanadze Democrats called for new elections, hoping to draw attention away from their poor showing in the election results. The $\mathrm{N}$ ational Movement called for the president's resignation, a call that soon caught on with all the demonstrators and leaders, and demanded that it be recognized as the election's true winners. Throughout this period, tensions between the rival Burjanadze Democrats and the National Movement and their leaders, which had prevented pre-election unification, remained strong.

The government bloc responded to the demonstrations by waving the bloody shirt of destabilization, the last refuge to which an authoritarian, even a soft one like Shevardnadze, clings. The president also belittled the protests, maintaining that only he could guarantee stability in

Georgia and that he would not resign because of "a few hundred kids." Other opposition parties, such as Labor and New Rights, opposed the demonstrations from the start, a mistake that cost them a great amount of support.

Ajaran leader Aslan Abashidze made clear his support for President Shevardnadze. Ajaran television ran spots comparing Saakashvili to Hitler and Zhvania to a molting snake, while Revival party leaders warned of a fascist takeover of Georgia led by Zhvania and Saakashvili. During this time Shevardnadze made a trip to Ajara and stood publicly with Abashidze to emphasize their support for each other.

By mid-N ovember, the two sides had arrived at a deadlock. The protesters kept up their vigil, but the president refused to resign as the government continued to count the votes. On November 14, the biggest demonstrations up to that time occurred as more than 20,000 people jammed the streets in front of Parliament. However, at the end of that night Saakashvili, by then the undisputed leader of the opposition, told the demonstrators to go home and await further instructions. The crowd peacefully dispersed. Unclear calls for civil disobedience began the following day, while rumors of an inevitable deal persisted.

The week of N ovember 17 began relatively quietly amid rumors that Abashidze was sending people from Ajara to Tbilisi, the capital, to occupy the space in front of Parliament and show support for
Shevardnadze. Tenaciously, Saakashvili refused to back down and said he would bring people in as well to reclaim the space. By late in that week, the possibility of clashes between opposition demonstrators and Ajarans appeared to threaten the nonviolence that until then had characterized the protests. (A clash was avoided on the weekend of Shevardnadze's resignation when Abashidze's supporters left the space in front of Parliament shortly after Saakashvili and his supporters entered the building - indicating that loyalty to Abashidze did not translate into loyalty for Shevardnadze.) Tensions were exacerbated on the evening of N ovember 20 when the government issued the final election results, which were clearly fraudulent, and announced the new parliament.

The turning point occurred on November 22, when Shevardnadze sought to seat the new parliament. Had he succeeded, the moment of opportunity for the opposition would have passed because the new legislature would have immediately elected a new pro-government speaker. According to the constitu-

tion, the speaker of Parliament assumes the presidency if the president is incapacitated or resigns. If the speaker then in office-opposition leader Nino Burjanadze - had been replaced by a progovernment speaker, there would have been no use demanding Shevardnadze's resignation. Therefore, the opposition disrupted the seating of the fraudulently elected parliament as soon as a quorum had been reached. The moment Shevardnadze allowed himself to be hustled out the door by his security guards, an image televised around the world, it was over. The emperor was finally revealed to have no clothes.

Shevardnadze hung on as president for another 30 hours, but his fundamental weakness had been exposed. There was no sector of society in Georgiano ethnic group, social class, or geographical areato which he could turn for support. Even in Ajara, the relationship between Abashidze and Shevardnadze did not bring any real support for the president. The only people still backing Shevardnadze were those who were individually enriching themselves through his presidency. This became clear to Shevardnadze as Saturday night and Sunday wore on. So, after first insisting that he would not leave office, by Sunday evening even Shevardnadze saw he had nowhere to turn, and resigned. Burjanadze under the constitution became acting president. 
The consolidation of the democratic breakthrough of N ovember 2003 continued with Georgia's presidential and parliamentary elections in January and March 2004, respectively, in which Saakashvili was elected president in a landslide and the $\mathrm{N}$ ational Movement party of Saakashvili, Zhvania, and Burjanadze won a huge majority in Parliament. Zhvania was appointed to the newly created position of prime minister; Burjanadze returned to being speaker of Parliament. Both the presidential and parliamentary elections were viewed as generally free and fair. The elections demonstrated that, while the N ovember 2003 demonstrations may have been small, the democratic sentiments they expressed were supported by a substantial majority of Georgians.

How did the undersized protests following the fraudulent elections of 2003 lead to Shevardnadze's resignation and the Rose Revolution? A number of factors were at play, not least the fundamental weakness of Shevardnadze's administration, resulting from his failures as president. But most critical were Georgia's vibrant civil society; the sometimes ambiguous role of the international community, us and European governments, and private foundations; the opposition's belated unity; and the destructive role played by the Revival party and the Ajaran authorities.

\section{FerTILE CIVIL SOCIETY}

Georgia during the Shevardnadze years was one of the freest post-Soviet countries, featuring a vibrant civil society and numerous interest and advocacy groups. Shevardnadze claimed-and deserved-a fair amount of the credit for this. Georgians may have suffered from rampant unemployment, unreliable energy delivery, a corrupt and ineffective government, and a deteriorating infrastructure, but they did enjoy political freedom. And Georgia's weak economy helped contribute to the vibrancy of NGOS. For honest Georgians seeking to make a good living, the civil sector was the place to work because NGOs were funded by foreign money and could pay decent salaries. By 2003 many of Georgia's best and brightest were working for NGOS.

In addition to civic organizations, a culture of activism had emerged; Georgians were not afraid to demonstrate their discontent following the elections. While the protests did not reach large numbers until the weekend of Shevardnadze's resignation, there was little attempt to repress them. The groups that harried government officials for months and mobilized students to participate in the demonstrations, that monitored the elections and announced how fraudulent the results were, and that publicly criticized the government for illegal and corrupt behavior- as well as the thousands of citizens who took to the streetsdemonstrate how important civil society and political freedom were in the Rose Revolution.

The media played an equally important role, most notably the pro-opposition tel evision station, Rustavi 2. Georgian electronic and print media during the Shevardnadze years were very diverse and included strongly antigovernment opinions. The barriers to information for many Georgians were not censorship, but the frequent blackouts that made it difficult to rely on television news, and the poverty that made it difficult for some to pay for newspapers. During the pre-election period, Rustavi 2 covered the opposition consistently, providing a regular platform to Zhvania, Saakashvili, and other opposition leaders. Rustavi 2 also helped fund the exit poll, which it then publicized after the election.

Lost in the celebration of the Rose Revolution is the reality that only beginning on N ovember 22 was it a mass movement. During most of the vigil, crowds were considerably less than 5,000 people. The rhetoric of the opposition, particularly Saakashvili's, appeared out of place for what seemed like small demonstrations largely by the political class. This was clear to anybody who walked by the demonstrations, as I did.

But most Georgians did not walk by the demonstrations. They watched them on television, mostly on Rustavi 2. Rustavi 2's coverage of the protests was almost nonstop, except to provide periodic interviews and roundtables with opposition leaders- who often used the opportunities to inform Georgians about upcoming demonstrations and actions. Moreover, the station always showed images of demonstrators tightly packed together, shying away from aerial shots that might have shown that the protesters were crowded in a relatively small space. Rustavi 2's image of the vigil differed just enough from reality to give viewers the impression that there really was a mass movement actively supporting Saakashvili and the opposition.

\section{IN TERN ATIO NAL NOURISHMENT}

The US and European governments sought to support both Shevardnadze and democracy in Georgia. Washington backed Shevardnadze because his government supported America's major foreign policy goals, and because strong personal ties existed at the highest levels of the two governments. Shevardnadze often spoke of his friendship with former Secretary of State James Baker, the Bushes, and other high-ranking officials. It was thus 
difficult for many international figures to realize that Shevardnadze himself had become an obstacle to democracy in Georgia. Many preferred to think that he was doing his best and that the opposition just needed to be more patient.

Contrary to Shevardnadze's claim after he was deposed, the diplomatic and foreign-assistance communities did not wholeheartedly support the opposition. In fact, for much of 2003 Zhvania and Saakashvili accused the United States of being too timid in its criticism of Shevardnadze, particularly regarding issues of election fairness. American organizations such as the $\mathrm{N}$ ational Democratic Institute, for which I worked at the time, worked more with the opposition. But we were always aware that if we were seen as too close to Shevardnadze's opponents it would hurt us, not least with our own us government. To the Georgian president and his supporters this nuance was hard to discern. Instead, they saw millions of American dollars going to often highly effective and committed NGOS and watchdog groups, which they viewed, often correctly, as opposing the government's agenda.

In addition to the diplomatic help and assistance money, the Rose Revolution received critical support from us-based philanthropist George Soros. It was Soros who encouraged what became known as the "Serbian model." He paid for several trips and exchanges between Georgian and Serb activists and politicians, during which the Georgians gleaned lessons from Serbs who had helped defeat Yugoslav President Slobodan Milosevic. Soros's Open Society Georgia Foundation was a major funder of the exit poll that hel ped reveal the extent of election fraud, along with other democracy and election fairness projects. And because they were not funded by a foreign, friendly government, Soros's representatives in Georgia could be more outspoken in their criticisms of Shevardnadze's regime.

us assistance to Georgia was critical. It included study and young leaders programs that allowed people like Saakashvili to learn about politics in the United States; democracy-assistance programs such as the National Democratic Institute, which helped nurture coalitions among democratic political groups; funding for domestic organizations that monitored the elections; and a degree of support for the opposition leaders. Both Saakashvili and Zhvania had spent years cultivating relationships with American politicians, NGo leaders, and government officials. These relationships were sources of encouragement and support during the period leading up to and including the Rose Revolution. However, had the Rose Revolution failed, the opposition would likely have accused the United States of not supporting it strongly enough. America's close relationship with Shevardnadze and its unwillingness to recognize Shevardnadze's turn away from democracy are easily overlooked now.

\section{THE OPPOSITION UNITES}

Another factor that played an important role was the putting aside of divisions among the opposition. Within 48 hours of the polls closing on November 2, Saakashvili and Zhvania, who had only recently been political foes, and Burjanadze found their political futures tied inextricably together. However, they had different goals. Zhvania and Burjanadze at first wanted to secure a place in the new Parliament: contrary to the data from the parallel vote tabulation and exit polls, initial official returns showed their party below 7 percent-the threshold for election to the legislature. Saakashvili's National Movement wanted to be recognized as the election winners based on the same data. Within two days signals came from the authorities that the Burjanadze Democrats had made it past the 7 percent threshold. Some saw the announcement as a clumsy attempt by the government and the Central Election Commission to separate the interests of the two parties. There was speculation that a deal had been made whereby the Burjanadze Democrats would be guaranteed a place in Parliament if they stopped supporting the N ational M ovement.

The Burjanadze Democrats realized, however, that getting 7 percent or 8 percent of the votes, significantly less than they thought they had earned, would prove a Pyrrhic victory. To a great extent they felt this way because they did not want to be in a Parliament dominated by the government bloc and Saakashvili's National Movement. Briefly, Burjanadze Democrats even spread somewhat implausible rumors that the government had collaborated with the National Movement during the election as part of a plan to exclude the Burjanadze Democrats from political power.

So, in a bold stroke of partial genius, the Burjanadze Democrats called for new elections and then announced that if new elections were not held, they would boycott the new Parliament and not 
take the seats they had earned. This position underscored the extent to which the elections had been fraudulent, but it was also perceived as an attack on the National Movement because it implied that that party's defeat of the Burjanadze Democrats was somehow illegitimate. The National Movement maintained that, whatever else had happened in the election, Saakashvili had proved that he was far more popular than Zhvania or Burjanadze. Saakashvili did not want to have all the returns thrown out. The National Movement simply wanted to be recognized as the winner of the election, or to see Shevardnadze resign.

These machinations occurred behind the scenes. Publicly, the opposition parties presented an image of unity. And this unity, while strained from the beginning, was absolutely essential. Shevardnadze would have been able to defeat any of his former protégés individually; with the three leaders together, the president was in a far more difficult position. According even to the exit polls and parallel vote tabulations, the National M ovement and Burjanadze Democrats spoke for at most only 45 percent of the electorate, but a majority of the country's top organizers and committed activists identified with one of these parties.

Saakashvili's seemingly hopeless demand for President Shevardnadze's resignation was viewed more seriously because he was joined by Zhvania and Burjanadze, who both enjoyed reputations as being more moderate than Saakashvili. Similarly, Burjanadze and Zhvania did not have enough popular support to mobilize people or make strong demands on the government without the backing of Saakashvili and his party. It was clear that if the opposition parties fought among themselves, as they had for most of 2002 and 2003, Shevardnadze, not his opponents, would drive events.

\section{FRIEND OF THE DEVIL}

Also working against the president were the coalition partners that he sought out in his moment of crisis. Until May 2004, the region of Ajara in southwest Georgia was governed not by the authorities in Tbilisi, but by Abashidze and his Revival party. Abashidze was a dictator who exercised complete power over Ajara, where people had significantly less freedom of speech and association than their conationals in the rest of Georgia.

Elections in Ajara also were less free. Because two-thirds of Georgia's Parliament is elected by a single-list party vote, rigged elections in Ajara gave Revival a disproportionately large representation in the legislature. On November 2, 2003, few were surprised by election fraud in Ajara, but its extent was by most measures the worst in Georgia.

The relationship between Abashidze and Shevardnadze had always been complex. Although Abashidze publicly identified himself and Revival as part of the opposition, the two leaders, through their parties, had cooperated extensively on the Central Election Commission as well as in Parliament, and Abashidze had criticized the other opposition parties. However, Revival and Abashidze were still disliked outside of Ajara for their undemocratic regime and their constant threats of secession from the rest of Georgia.

When Shevardnadze turned to Abashidze for help in November 2003- he was the only politician who could offer real resources and support- it infuriated the Georgian people, who saw the two as partners in election fraud. Shevardnadze exacerbated this sentiment when he flew to the Ajaran capital of Batumi after the election to appear publicly with Abashidze. The latter's support for Shevardnadze included sending busloads of Ajaran toughs into Tbilisi to occupy the space in front of Parliament after the vigil ended on N ovember 14, making it clear to the public that Shevardnadze was the one raising the threat of violence and to the demonstrators and their leaders that the situation was beyond negotiation.

After Shevardnadze's resignation, Abashidze's support among Ajarans began to erode as they saw the changes being made in the rest of their country. In May 2004 peaceful demonstrators in Ajara, supported by the Georgian government, forced Abashidze to flee to Russia in an episode viewed by many as phase two of the Rose Revolution. Ajara held democratic elections in June.

\section{THE FIRST SECRETARY'S NEW CLOTHES}

It is now easy to forget that in the days immediately following the fraudulent N ovember 2003 election, Georgia's opposition appeared weak and disunified. It seemed to lack strong support within Georgian society, an effective leader, a cohesive strategy, or any feasible demands. Saakashvili was quickly emerging as the principal opposition figure, but many believed he lacked the temperament to lead. His calls for Shevardnadze's resignation seemed desperate and unrealistic. Initial promises to fill the streets with demonstrators brought well under 10,000 in front of the Parliament. The opposition did not seem to have a plan that covered more than just a few hours or a day. 
Fortunately for the opposition, Shevardnadze's regime was even weaker. During his 10 -year rule as president, Georgia's government had devolved into a weak kleptocracy. The government could not in any meaningful way deliver basic services, begin to repair Georgia's crumbling infrastructure, enforce the law, or collect taxes. Georgia's weak state could best be summed up by an old joke: the government was bad, but at least there was not much of it. As first secretary of the Georgian Communist Party from 1972 to 1985, Shevardnadze had been a powerful autocrat running his own fiefdom in a remote corner of the Soviet empire. As president of independent Georgia, he became an ineffective leader who could not get 20 percent of the vote for his own party in a fair election.

Beginning in 2000, most of the bright, reformoriented leaders and activists in the Citizens Union of Georgia left the party, many to join Saakashvili or Zhvania. As a result, the only people left around Shevardnadze by late 2003 were corrupt officials like Levan Mamaladze and bitter politicians like Irina Sarashvili-Chanturia. N one of these people could-or wanted to-explain to Shevardnadze just how weak he was.

As the events of N ovember 22-23 unfolded, it became evident that Shevardnadze did not realize how feeble his position had become. Even after he was rushed out of Parliament by his own security team, a gesture that bespoke weakness to millions watching on tel evision around the world, Shevardnadze still tried to cling to power. He briefly addressed the remaining pro-government demonstrators from Ajara outsi de of Parliament and again asserted his unwillingness to resign.

After he finally left office on N ovember 23, Shevardnadze made a last attempt to salvage his historical legacy. He insisted he had resigned to avoid bloodshed. This claim, although nicely consistent with the overall nonviolent tone of the Rose RevoIution, was not entirely accurate. In reality, Shevardnadze resigned because, finally realizing his own weakness, he became aware that he no longer controlled the military and security forces. Bloodshed was avoided largely because the president was too politically weak to command it.

\section{THE PROTÉGÉS' CHALLENGE}

In Georgia in the days following the Rose RevoIution there was much talk about the Serbian model. The analogy was not precise - Shevardnadze and Milosevic were distinctly different types of leaders with very different relationships with the United
States and NATO. But in both systems an active civil society and eventual unification of the opposition laid the groundwork for change, and a stolen election became the catalyst.

The relatively open Georgian society; the international community's support for reform; the weakness and failure of the Shevardnadze administration; and elections conducted more fraudulently than almost anybody- even most Georgian voters- expected, all contributed to the Rose Revolution. A unique relationship and belated cooperation among the opposition leaders-Saakashvili, Zhvania, and Burjanadze - as well as some critical missteps by the government, which the opposition skillfully exploited, also played an important role. Now the hard work begins as Shevardnadze's former protégés confront the enormous task of building not only Georgian democracy, but the Georgian state.

The nine months since the Rose Revolution have seen some meaningful changes in Georgia. Three elections have been held, two nationwide and one in Ajara, that were remarkably free and fair by the standards of the former Soviet Union. Saakashvili and his government have taken strong steps against corruption at all levels of Georgian society. $\mathrm{H}$ is nonviolent triumph in Ajara was extraordinary, and surprised many. However, in recent months, Saakashvili's attempts to expand the Rose Revolution to Georgia's two other restive regions, Abkhazia and South Ossetia, have been far less successful, and the threat of Russian interference remains.

\section{A C urrent History Snapshot ...}

"If Soviet leaders calcu-

late on the basis of a

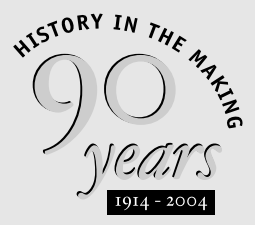

broad correlation of forces and not simply on a narrow ratio of weapons, they cannot ignore the geopolitical problems on their frontiers- in Poland and Afghanistan and China. ... A superpower bogged down in efforts to shore up its immediate weakness and driven by fears of encirclement may be entering a period of decline."

"The Soviet Union and the United States" Current History, October 1981

William G. Hyland,

Carnegie Endowment for International Peace 